\title{
Actual Problems of Digitalization in the Field of Indus- trial Safety Management
}

\author{
Oksana Nurova ${ }^{1, *}$ \\ ${ }^{I}$ Institute of Engineering and Environmental Safety, Togliatti State University, Togliatti 445020, Russian Federation \\ *Corresponding author.Email: oksana.nurova@gmail.com
}

\begin{abstract}
In the modern world, the problems of digitalization of labor safety processes at industrial enterprises are relevant. The purpose of the study is to identify the specifics of industrial safety management in the implementation of a digitalization policy, to identify problems and prospects for introducing digital transformation of an enterprise. The study is aimed at analyzing the digitalization of industrial enterprise management, substantiated the need for digital modernization of production systems of enterprises. Information on advanced production technologies that ensure the safety of processes is considered. The article analyzes the concepts of new management of an industrial enterprise and considers the advantages of introducing innovative technologies. The author comes to the conclusion that during the period of digitalization, the management of an industrial enterprise is possible if the head of the organization has specific professional competencies in the field of IT technologies. Today, in the Russian Federation, the development of production systems of enterprises covered by elements of digital technologies is at a low level and is characterized by a low level of integration into the enterprise management system.
\end{abstract}

Keywords: Digitalization problems, industrial enterprise management, labor protection, modernization, technologies, factors.

\section{INTRODUCTION}

Innovative technologies are used in every sphere of human activity. In Davos, Schwab, President of the World Economic Forum, formulated the concept of Industry 4.0. The monograph "The Fourth Industrial Revolution" became the basis for the development of interstate and national initiatives for digitalization of industry [1]. In the EU countries (Germany, Italy, Sweden), these initiatives are called Industry 4.0. (Smart Industry) [2].

In the context of digitalization, the relevance of issues related to the specifics of managing an industrial enterprise is of particular importance. So, for example, according to the research of the World Streel Association, with the production of only $6 \%$ of the world, $26 \%$ of deaths in metallurgical production from the global indicator occur in the CIS countries. Fatality frequency rate (FFR) in the CIS countries is 0.056 , twice the world average of 0.030 [3].

The key aspects of reducing production safety are: high depreciation of fixed assets of enterprises, a formal approach to ensuring safety, lack of consistency in industrial safety management. The digitalization of security management processes creates an additional level of protection, protecting against the occurrence of system errors, reducing the risk of accidents.
Thanks to the technologies of the Internet of Things, personal wearable devices, artificial intelligence, it has become possible to manage an enterprise based on the collection of large amounts of data. The main task of introducing innovations in the field of industrial safety management and labor protection is the prevention of undesirable events in advance, preventive measures. Increasing production efficiency, increasing the level of trouble-free and safety of technological processes, reducing the incidence of industrial injuries and deviations is the goal of introducing innovative production methods based on digital solutions.

At the same time, there are a number of problems associated with the introduction of digital technologies in industrial safety management. One of them is legislative gaps or restrictions related, among other things, to the ability to process biometric data, which entails an additional financial burden on enterprises.

In the Russian Federation, more than 90,000 enterprises are involved in industrial safety management, which need to comply with the requirements of state bodies (Rostekhnadzor) and internal enterprise safety standards. The industry, in turn, dictates high requirements for ensuring the safety of production and the safety of people's lives. 
The aim of the study is to analyze the specifics of digitalization of industrial enterprise management, identify the algorithm for the digital transformation of an enterprise. The success of the digital transformation policy largely depends on: the availability of professional personnel, material and financial resources and a management system. The factor holding back the development of digitalization in our country is socio-economic, legal and political.

The objectives of the study were: analysis of the state of digitalization of industrial enterprises in Russia; research of problems, as well as features of innovative potential in the context of industry digitalization.

\section{LITERATURE REVIEW}

In his study, Bubin analyzes the need to use recycling in the modern conditions of the development of the digital economy and proposes measures within the framework of state participation [3]. In addition, Kosareva for the implementation of the transformation process by the enterprise, he offers an adaptive algorithm, which consists in creating an expert group, researching the activities of the enterprise, implementing a roadmap, developing and testing [4].

Petrov explores the prospects and problems of introducing digital technologies into the Russian economy, the negative consequences of digitalization, aspects that hinder its development [5]. In the same time, Komarova in his article considers the need to adapt the Russian economy to the requirements of the new technological order, identifies the main challenges of the digital economy in Russia [6].

Fundamental studies of the transformation of the international economy in the framework of technological change are reflected in the works of Rosser [7].

In the article by Asabin examined the term "digital economy" and highlighted its elements, indicated examples of the application of IT solutions for Russian enterprises [8].

Kostyukhin, Savon, Safronov, Zhaglovskaya in their study, they propose to use specialized software in mines, as an element of effective control, to help block replacement orders when they are issued, in order to eliminate an emergency [9].

Toropygina, Zavyalov considered in their work the goals, objectives, principles of introducing innovations into the labor protection management system and digitalization. New methods and technologies in labor protection management are analyzed [10].
Trifonov, Verzhansky, Zamriy, Rusetsky studied innovative approaches to solving industrial safety problems [11].

The relevance of the digitalization of the Russian economy through an increase in economic efficiency, an increase in the competitiveness of industrial enterprises is proved in the study of Kiselev [12]. Afonasova explores the issues of digitalization of production in the context of the problem of increasing the operational efficiency of business, the transformation of production processes of enterprises at the stage of digitalization [13].

During the research, general scientific methods of cognition were used. The information retrieval method made it possible to collect the necessary materials on the research topic. To achieve the goal of the study, the collection and processing of the information received was used. By analyzing existing sources, it was possible to solve the set tasks. Methods of comparisons and analogies made it possible to identify a promising direction of digitalization of industry. The conclusions and results of the study are based on logical methods and generalization.

Up-to-date information on the research problem is contained in the reporting data of the research conducted by world companies. The research is based on statistical and information materials of rating agencies. Analytical materials made it possible to identify the problems and prospects of the digitalization of industry in Russia. Materials of international and all-Russian conferences were used to study the main trends in the use of digital technologies in industrial safety management. The information base of the research was the materials of the Internet, located in the open access, scientific periodicals and publications of scientists, practitioners and specialists.

\section{DIGITALIZATION IN INDUSTRIAL SAFETY MANAGEMENT}

The pursuit of automation of systems and the development of digital technologies for use in solving daily problems is becoming an international trend in all types of production. Reducing the involvement of the human factor leading to an accident or accident is the task of automating processes. Digitalization is also necessary for the development of industrial safety itself. The first attempts at "digital" were made by the largest Russian manufacturers.

The companies shared innovative projects implemented in their production facilities at the Russian Steel Congress (2019), which was dedicated to industrial 
safety. In 2016, PJSC Gazprom Neft became the first company in Russia to implement the electronic work permit system. PJSC SIBUR Holding is testing drones that monitor specific areas, digital work permit and black screens. The black screen system on the monitor displays gray, or normal, production mode. The appearance of black screens indicates a process failure. This is a visual alert to the operator for urgent action. The remote monitoring system is being tested at one of the enterprises of PJSC SIBUR Holding together with Rostekhnadzor. Digitalization tools are implemented in industrial control processes faster and easier than in the processes that are associated with the investigation of incidents.

PJSC MMK is modernizing Industry 4.0 in the field of labor protection and industrial safety. Since 2018, an accident investigation module has been integrated into the information system. The principle is built on the basis of an analysis of incidents over the past 10 years. The main developments in the field of industrial safety are "smart" helmets and vests with sensors that allow tracking the location and physical condition of an employee. The video analytics system, which records the incident and signals the problem, allows to reduce the damage with the help of high response speed. VR simulators are used in the process of teaching employees to behave in non-standard or emergency situations. Pilot projects were developed to maintain electronic passports for employees. Information about medical examinations, completed training and instruction courses, a medical record, a list of work permits issued to the employee's name are combined in a single electronic document. The use of predictive analytics systems is the basis for the implementation of developments for the digitalization of information management on industrial safety and equipment integrity management.

IoT technologies (digital twins) are most applicable in industry. A "twin" computer model is created for objects and processes, which allows solving the problems of forecasting real dangers and threats before they occur. Platforms for the implementation of digital twins, the most popular technologies containing sub-technologies of digital design and mathematical modeling, were included in the roadmaps for promoting end-to-end digital technologies for 2019-2024 [14].

Digitalization increases the responsibility of personnel in industrial safety management. Launched in 2018. The digital industrial safety management system at the Kazan State Treasury Gunpowder Factory made it possible to create a unified information space for the enterprise, ensure traceability of activities, and timely conduct industrial safety examinations.

\section{PROBLEMS OF DIGITALIZATION IN THE FIELD OF INDUSTRIAL SAFETY MANAGEMENT}

According to experts, the legislative base in the field of industrial safety management is imperfect. The introduction of digitalization in industry is hampered by outdated and outdated laws and regulations, ministerial instructions of the Soviet period and the modern Russian Federation. The development of an up-to-date regulatory framework is a big practical problem in the implementation of an industrial digitalization project. There is a significant lag in this area. At the St. Petersburg International Economic Forum (SPIEF) in 2019, the participants summed up that in the field of digitalization, out of 100 necessary bills, the Russian State Duma adopted only 2.

It is necessary to give more opportunities to businesses in paperwork, automation and digitalization. The regulatory framework in the area of industrial digitalization requirements has not kept pace with innovative technical capabilities. For example, there are no requirements for the introduction of electronic work permit. The so-called "pilot" projects are being launched at the enterprises. The legal basis for the introduction of electronic work permits was the Federal norms and rules in the field of industrial safety "Rules for the safe conduct of gas hazardous, hot and repair work" (approved by order of the Federal Service for Environmental, Technological and Nuclear Supervision of November 20, 2017 No. $485)$. The rules for using electronic signatures when coordinating work permits are approved by the internal documents of the operating organization in accordance with the requirements of the Federal Law of April 6, 2011 N 63-FZ "On electronic signature". For example, the main functionality of the "Electronic work permit" module of the digital system "MyObject.rf": automation of the registration, coordination and approval of the work permit using a digital signature; management, control, notification of participants in the process about the preparation and progress of work on the work permit; provision of operational information on RPO carried out on the territory of the enterprise; data entry control; accounting of all hazardous work carried out on the territory of the enterprise; keeping checklists and reference books; display of all current and planned works with dynamic statuses (agreed, under revision, in progress, suspended); integration with the enterprise information system.

By presidential decree, the government is preparing a regulatory framework for the digitalization of industry. The main task is to eliminate outdated, contradicting and 
duplicating legislative acts. There is a need to eliminate old legislation and introduce new, targeted, risk-oriented legislation. Regulatory documents should prevent or mitigate risks, while the cost of activities should be lower than the risks themselves. Normative acts should not be aimed at regulating the internal procedures of enterprises, dictating the definition of the risk management vector. Today, a new law on industrial safety aimed at improving the system based on modern requirements, within the framework of the Vision Zero concept and modern digital achievements is under development. They attach particular importance to hazardous industrial facilities, welding and mine surveying, safe work with mobile devices and explosives, new requirements in the diagnosis of buildings and structures, and industrial safety expertise.

From the point of view of experts, in the Russian Federation, the development of industrial digitalization is at a low stage, consists of non-systemic, individual solutions.

Large sample sizes in surveys showed that $37 \%$ of enterprises are already actively using digital technologies, $27 \%$ have begun to implement elements of technology. The remaining respondents are only considering the feasibility of their implementation. Company representatives note that risk hedging measures are needed [15].

Experts note that the following factors hinder the successful digitalization of industrial safety management in Russia: lack of qualified personnel, lack of a developed strategy, insufficient interaction between IT and enterprises, low funding, presence of risks and views of management, company employees do not have the necessary knowledge and competencies, technological processes built inflexibly and not fast enough, modern and implemented technologies are often incompatible, the use of irrelevant technologies, lack of motivation for innovation [16].

The inaccessibility of modern digital developments is a serious problem of industrial digitalization. Currently, in Russia, its own technological developments in the field of digitalization are produced in insufficient quantities. This is confirmed by the fact that out of 10 global companies that develop digitalization technologies, 9 are American and 1 is Chinese. The innovative leaders in this area are 12 companies from the USA and 9 from China [17].

Another problem in the development of industrial digitalization is the lack of an efficient digital infrastructure. For example, the use of high-speed industrial Internet $(5 \mathrm{G})$ in the near future. Also, this infrastructure includes equipping industrial processes with sensors, with the help of which data is read and processed, the generation of computing power for predictive analytics [17].
Industrial production is becoming dependent on the applied information and communication technologies. According to the European Network and Information Security Agency (ENISA), the first three negative factors that can cause financial damage include the introduction of the Internet of Things. Business representatives do not see profitability in the digitalization of production, since the introduction of digital technologies is an organizational and technically complex process.

\section{CONCLUSIONS}

The main problems of digitalization in the field of industrial safety management include:

- Inconsistency of the regulatory framework with technological changes taking place, but at the current stage of development;

- Low qualifications of competent personnel, lack of human capital;

- The emergence of new technologies and applied solutions that require infrastructure modernization;

- Lagging behind the digital infrastructure in the Russian Federation, the need for significant scientific, financial and time resources. For example, in 2018. PJSC Gazprom Neft invested RUB 1.7 billion to develop a special occupational health and safety program.

The formation of a corporate safety culture is one of the main tasks of enterprises. Oil workers implement personal obligations for all employees, conduct Leadership behavioral safety audits at enterprises.

The transformation of industrial enterprises: digital, operational, cultural organizational - should be carried out in an integrated manner. Today, many enterprises are limited to a system of incoherent, scattered instructions and measures. It is possible to build an integrated system for a specific production in two or three years.

With the integration of digital technologies into the work of enterprises, the variability of production increases by actively changing the characteristics of the production process and providing the information component of the stages of the life cycle of manufactured products. Along with this, the degree of efficiency of enterprises' work from the efficiency of the applied digital technologies increases. Disruption of integrated digital systems can lead to significant risks when compared with the traditional model of enterprise production management.

Modern digitalization forces industrial enterprises to reorganize their activities, to integrate new information systems in production. Experience shows that off-theshelf technologies cannot always be incorporated into an existing system. It is not always possible to eliminate risks and accelerate the process of transformation of 
technological processes of an enterprise at all stages using existing tools and techniques.

The main business risk of digital transformation of an enterprise is the lack of tools for calculating the effectiveness of the integrated implementation of digital tools. A recent survey of more than 600 executives from mining and metals companies showed that more than a third of respondents either know nothing about today's digital realities or have a very vague idea of them. Many enterprises lack modern instrumentation systems and automated production technology management systems. The automation device continues to work on relay logic, which does not allow it to be physically connected to the level of modern services and analytics.

Digital technologies have different potential for use by industrial enterprises. Not all technologies are currently sufficiently regulated at the state level, and key technologies to a lesser extent. Based on the analysis of state regulation abroad, additional regulatory measures can be proposed.

In general, the basis of information security should be the predominant use of domestic software and equipment, Russian technologies for ensuring the integrity, confidentiality, authentication and availability of transmitted information and its processing processes, as well as the use of information protection technologies using Russian cryptographic standards.

Opportunities and advantages of digitalization are rarely questioned, including in our country, however, according to the study "Digital funnel" of consumption: features and prospects of the Russian IT market ", Russia lags behind Western countries in digitalization by 6 years. Statistics show this:

1. The share of the digital economy in Russia is $5 \%$, in Western countries - 16-35\%.

2. The number of innovative industrial enterprises in Russia - $11 \%$, in some Western countries - up to $60 \%$.

3. The number of employed in high-tech / knowledgeintensive industries in Russia - 4\%, in Western countries $-6 \%$.

Experts identify 4 reasons at once for Russia's lag behind the leading countries in the field of digitalization:

1) Instability of the economy, exacerbated by sanctions. There are few manufacturers of high-quality hardware in Russia: processors, sensors, modems, etc., while foreign products are expensive and sometimes simply unavailable for the domestic market.

2) Lack of clear standards. For the effective development of the high-tech market, IT standards are required, which are just beginning to appear in domestic legislation. Certain processes are not at all structured at the state level, which greatly inhibits the introduction of digital technologies.

3) Lack of qualified specialists. The country's educational system lags behind the development of the digital technology market and does not have time to provide interested companies with high-quality personnel.

4) Striving of the business for quick profit. Many domestic companies are only interested in the most liquid projects that can bring large income in the short term. In Western countries, corporations are happy to invest billions of dollars in projects with a payback period of 30 years, our companies are trying to invest only in those technologies that will pay off in two years. Therefore, digitalization is generally less attractive for domestic businesses.

Unfortunately, many enterprises are not yet able to grasp the full potential of digitalization and the possibilities of transition to new technologies.

\section{REFERENCES}

[1] K. Schwab, The fourth industrial revolution, Penguin, 2017, $192 \mathrm{p}$.

[2] Tsifrovaya ekonomika: global'nye trendy i praktika rossijskogo biznesa (2017) https://imi.hse.ru/pr2017_1. Accessed on 21 June 2020

[3] World steel association (2019) World steel in figures https://www.worldsteel.org/en/dam/jcr:96d7a585-e6b24d63-b943-

4cd9ab621a91/World\%2520Steel\%2520in\%2520Figures\%25202019.pdf. Accessed on 21 July 2020

[4] M.N. Bubin, Recikling v sisteme upravleniya othodami $\mathrm{v}$ usloviyakh razvitiya tsifrovoy ekonomiki, in: sbornik statej i tezisov dokladov XXII mezhdunarodnoj nauchno-prakticheskoj konferencii Tsifrovye tekhnologii: ih rol' v ekonomike i upravlenii, Publishing house Pero, Moscow, 2018, pp. 11-16.

[5] I.N Kosareva, V.P. Samarina, The management features of the enterprises in the conditions of digitalization, The Eurasian Scientific Journal 3(11) (2019) 9.

[6] A. Petrov, Digitalization of the economy: problems, challenges, risks, Trade policy 1(154) (2018) 9-31. DOI: https://doi.org/10.17323/2499-9415-2018-3-15-931

[7] V.V. Komarova, Actual problems of introduction of digital technologies in the industry of Russia, Kreativnaya ekonomika 13(6) (2019) 1107-1116. DOI: https://doi.org/10.18334/ce.13.6.40782 
[8] J. Barkley, Jr. Rosser, V.M Rosser, Comparative Economics in a Transforming World Economy, MIT Press, 2018, 744 p.

[9] A.A. Asabina, Rol' tsifrovyh metodov v obuchenii rabotnikov ohrane i bezopasnosti truda. People-management v usloviyakh tsifrovoj transformacii ekonomiki, in: Materialy III Vserossijskoy nauchno-prakticheskoy konferencii, posvyaschennoy 110-letiyu FGBOU VO "Bashkirskiy gosudarstvenny universitet", FGBOU VO, Ufa, 2019, pp. 20-23.

[10] Yu.Yu. Kostyuhin, D.Yu. Savon, A.E. Safronov, A.V. Zhaglovskaya, Sovershenstvovanie sistemy upravleniya promyshlennoy sistemy upravleniya promyshlennoy bezopasnost'yu v ugol'noy otrasli, Gornyy informacionno-analiticheskiy byulleten 6 (2019) 184-192. DOI: https://doi.org/10.25018/0236-1493-2019-06-0184-192

[11] V.V. Toropygina, Ispol'zovanie novykh metodov i tekhnologiy V upravlenii ohranoy truda na zheleznodorozhnom transporte, Problemy bezopasnosti rossiyskogo obshchestva 2 (2019) 14-22.

[12] V.A. Trifonov, A.P. Vepzhanskiy, A.P. Zamriy, R.A. Ruseckiy, Aktual'noe sostoyanie promyshlennoy bezopasnosti na proizvodstvennykh predpriyatiyakh, Gornaya promyshlennost' 2 (2020) 36-44.

[13] M.I. Kiseleva, Industriya 4.0: ekonomicheskiye, tekhniko-tekhnologicheskiye i upravlencheskiye aspekty bezopasnosti, Molodye uchenye Rossii. https://C:/Users/natal/Desktop/статья/elibrary_42956656_86375253.pdf. Accessed on 23 May 2020 .

[14] M.A. Afonasova, Tsifrovizaciya kak instrument povysheniya effektivnosti promyshlennogo sektora ekonomiki, Ekonomika i predprinimatel'stvo 8 (2020) 46-49.

DOI: https://doi.org/10.34925/EIP.2020.121.8.007

[15] Minkomsvyaz' RF. Dorozhnye karty razvitiya «skvoznyh» tsifrovykh tekhnologij. https://digital.gov.ru/ru/activity/directions/878. Accessed on 20 May 2020.

[16] N.S. Ziyadullaev, T.I. Samatov, Upravlencheskiye aspekty obespecheniya ekonomicheskoy bezopasnosti promyshlennogo kompleksa regiona, Vestnik IE RAN 2 (2019) 46-60.

[17] Vsemirnoe issledovanie Digital IQ za 2017 god (2017) Tsifrovoe desyatiletie. V nogu so vremenem https://www.pwc.ru/ru/publications/global-digital-iqsurvey-rus.pdf. Accessed on 19 Feb 2020
[18] PMEF (2019) https://forumspb.com/news/news/itogi-raboty-pmef-2019. Accessed on 19 July 2020 